\title{
DETECTION OF VEHICLE SMUGGLING BY THE BORDER GUARD ON THE PODKARPACKIE SECTION OF THE POLISH-UKRAINIAN BORDER IN 2014-2020
}

\author{
Marek Delong ${ }^{1}$, Marcin Jurgilewicz ${ }^{2}$, Oktawia Jurgilewicz ${ }^{3}$ \\ 1,2Rzeszów University of Technology, Aleja Powstańców Warszawy 12, 35-959 Rzeszów, Poland \\ E-mails: ${ }^{1}$ m.delong@prz.edu.pl, ${ }^{2}$ m.jurgilewicz@prz.edu.pl, ${ }^{3}$ niemieco@prz.edu.pl
}

Received 18 August 2021; accepted 11 October 2021; published 30 October 2021

\begin{abstract}
The purpose of this article is to present the role of the Border Guard in detecting vehicle smuggling on the Podkarpackie section of the Polish-Ukrainian border in 2014-2020. Organized transfer of stolen cars from the European Union to the territory of the Commonwealth of Independent States and introduction of cars to the Polish customs territory excluding customs and tax duties is one of the most important threats to the security of Poland and the European Union. Uncontrolled smuggling of stolen vehicles is concentrated mainly in larger border crossing points, and the disclosed attempts show with considerable professionalism, specialization and organization of criminal groups, often with international connections.
\end{abstract}

Keywords: vehicle smuggling; Border Guard; Polish-Ukrainian border; security

Reference to this paper should be made as follows: Delong, M., Jurgilewicz, M., Jurgilewicz, O. 2021. 2021. Detection of vehicle smuggling by the border guard on the Podkarpackie section of the Polish-Ukrainian border in 2014-2020. Journal of Security and Sustainability Issues, 11, 489-496. https://doi.org/10.47459/jssi.2021.11.44

JEL Classifications:

Additional disciplines: political sciences and administration, law

\section{Introduction.}

The most significant threats to the security of Poland and the European Union for years include the organized transfer of stolen cars from the European Union to the territory of the Commonwealth of Independent States and the introduction of cars to the Polish customs territory excluding customs and tax duties. This is largely a consequence of the abolition of internal border controls and the growing demand for cars of prestigious brands. All this leads to uncontrolled smuggling of stolen vehicles, which is concentrated mainly in larger border crossings, and the revealed attempts prove a considerable professionalism, specialization and organization of criminal groups, often with international connections. The purpose of this article is to present the role of the Border Guard in detecting vehicle smuggling on the Podkarpackie section of the Polish-Ukrainian border in 2014-2020. The Border Guard guards the internal and external security of the state, counteracts terrorism, and organizes and controls border traffic. By cooperating with international organizations, it contributes to the reduction of illegal migration and transit of goods (e.g. harmful, toxic substances, nuclear or radioactive materials) between countries. The study uses materials from the Bieszczady Border Guard Unit showing the scale of the practice and the effectiveness of combating it. For comparison, data on vehicle smuggling on the Lublin section of the Polish-Ukrainian border, disclosed by the Bug River Border Guard Unit, are also presented. It was assumed that the Border Guard, despite the best training, the latest techniques and technologies, is not able to completely prevent the smuggling of vehicles across the eastern border of Poland. 


\section{Car crime in Poland}

The political changes and changes on the Polish borders contributed to a significant increase in border crime. In addition to illegal migration, the most common type of crime committed at the border was economic crime, including car smuggling. Individual people living in the border areas were involved in smuggling, but most of all organized crime groups. The groups organizing the smuggling use various smuggling methods, incl. by using registration certificates and plates from other vehicles, falsifying identification numbers and documents. It happened that a stolen vehicle was on a tow truck among those transported by legends. In order to conceal theft, car components with identification numbers are replaced. There is also the phenomenon of the so-called theft with the consent of the owner. It consists in the fact that the car was legally transported abroad (mainly Germany) by German citizens who later returned without the car, but with the vehicle's keys and documents. Then the owner reported the theft, thus gaining the amount from the sale of the car and insurance (Potakowski 2008, 201). Cars were also detained when the applicable customs regulations were omitted or deliberately violated when crossing the border, e.g. purchase bills were falsified in order to reduce their actual value, which was mainly caused by the high excise duty rate on old cars. Much of the vehicle smuggling was "made to order", particularly in the case of luxury cars. Initially, the phenomenon of shifting stolen cars took place mainly on the western border. The situation changed dramatically after the border was opened by the former USSR, and since then smugglers have been heading towards the market beyond our eastern border (Jurgilewicz et al. 2011).

The liberalization of border crossing rules in the European Union led to another sharp increase in car crime, including smuggling, document forgery and sham thefts (Pływaczewski 2001, 403). "The transport of stolen cars in Western Europe to the East - wrote Wiesław Pływaczewski - was carried out by professionally prepared smuggling organizations, often with an international composition. Taking advantage of the organizational paresis on the borders and the weakness of law enforcement agencies, car gangs managed to transfer several hundred thousand vehicles to countries in Eastern Europe, including Poland, and subject them to the process of $<$ legalization>" (Pływaczewski 2001, 400-401).

In 1991, 89 cars were detained, but two years later there were 1126 cars, of which 674 were stopped at the eastern border. The phenomenon of car smuggling grew from year to year - in 1994 smuggling of 2,243 cars was revealed, and in 1996 - 3,065 (Laskowska 2011, 97). Since 2001, there has been a visible decrease in the number of smuggled cars (in 2001, 1344 of them were detained, and in 2007 - only 730), which may prove the professionalism and effectiveness of the Border Guard in detecting this crime.

Starting from 2001 and later after Poland joined the European Union, car smuggling ceased to be so safe and profitable that many smuggling groups ceased their activities. The professional operation of the Border Guard also contributed to this fact.

The phenomenon of car smuggling has visibly decreased over time, and to a large extent only the exclusive model of car transfer "made to order" has remained. As a result of Poland's accession to the European Union and the signing of the Schengen Agreement concluded on June 14, 1985, and signed by Poland in 2007, controls at the internal borders of the Member States were lifted. As a result, in Poland this meant the lifting of border controls with Germany, the Czech Republic, Slovakia and Lithuania. Free movement through the sea, land and air zones had a decidedly positive impact on the dynamics of economic development, but at the same time it determined a whole range of threats, mainly of a cross-border nature, including organized crime, smuggling and terrorism. The burden shifted from the borders of individual countries to the external borders of the Union, which since the introduction of the Schengen Agreement have become the only barrier for smugglers (Przeor 2016, 262-263).

The largest European market for stolen cars are the countries of Eastern Europe and Asia. Poland has become a transit country for smuggling cars to the east. Criminals, in agreement with Polish and Ukrainian criminal groups, use couriers transporting cars to Ukraine, usually through the border crossing points between Poland and Ukraine located in the Podkarpackie Voivodeship. Leasing vehicles are most often transported in this way, 
where the driver of the vehicle uses a notary agreement authorizing him to travel outside the country. It should be noted that Poland is the main transit country for stolen cars in Western Europe. Vehicles are handed over to countries such as Russia, Ukraine, Belarus, Caucasian republics (Bąk 2011, 89). A significant part of cars is stolen for individual orders for replacement components. This is related to the effective protection of the eastern part and high prices of new spare parts in Poland (Lachacz, Łachacz 2012, 183). In Ukraine, which is both a destination and a transit country, the illegal trade of cars is one of the most serious forms of organized crime, posing a major threat to the country's security (Chwała 2011,29).

\section{The role of the Border Guard in the fight against car crime}

The most important task of the Border Guard is to protect the state border on land and at sea (Act of October 12, 1990 on the Border Guard). The Border Guard is also responsible for organizing and carrying out border traffic control, and also issues permits to cross the state border (Kamuda, Trybus 2013, 68). It prevents and counteracts illegal migration by controlling compliance with regulations and recognizing, analyzing and combating migration threats (Wiśniewska 2015, 92). Its tasks also include combating crime, including organized crime, and preventing illegal crossing of the state border by people and vehicles, as well as detecting document forgery (Mroczek 2011, 139).

It is a uniformed formation equipped with technical and combat means and competences necessary to perform operational, operational and reconnaissance activities. The Border Guard is a law enforcement agency that detects crimes (including organized crime) (Mroczek 2011, 139) and pursues the perpetrators through investigations and investigations (Hoffman 2011, 64). It cooperates with other services and authorities in order to identify and counteract terrorist activities. The formation is supervised by the Minister of the Interior and Administration. The body of government administration in matters of state border protection and border traffic control is the Commander-in-Chief of the Border Guard. Field units are commanders of units, border control posts, watchtowers and divisions.

The Border Guard was established on May 16, 1991, after the Border Protection Forces were disbanded. Already at the beginning of its operation, opinions appeared that the role of the Border Guard would be minor due to the decline in border crime. However, in retrospect, it turned out that the reality was completely different (Maksimczuk, Sidorowicz 2008, 128).

On March 29, 1991, Poland signed an agreement with the countries of the Schengen group, as a result of which visas for Poles to travel to the European Union countries were waived. The signing of the agreement resulted in the transfer of the European Union border to the eastern border of Poland, which in practice meant that there was no need to protect and control the western state border and the expansion of the organizational structure of the branches located in the east of the country (Wiśniewski, Piątek 2006, 26). A big challenge at that time was to strengthen the eastern border, which was an entry buffer to the European Union. The effectiveness of its protection influenced the security of all European countries. New border crossings, watchtowers and border control posts were created, gradually transferring forces and resources mainly from the western and southern borders. When the Border Protection Forces were disbanded, there were 28 watchtowers on the border with the USSR, 73 watchtowers on the border with Czechoslovakia, 32 watchtowers with Germany, and 14 watchtowers at the sea border. Border and customs controls at the borders of European countries have undergone many changes. Initially, controls were carried out by both neighboring countries, then controls were carried out by one country in the direction of entry, selective controls were carried out, and finally, after Poland's accession to the Schengen area on December 21, 2007, the internal borders of the European Union were eliminated, as a result of which operational activities and controls were eliminated. conducted by them (Majer, Seroka 2017, 356). At that time, the Border Guard gained new powers, which include the control of the legality of the stay of foreigners throughout the territory of the Republic of Poland (Hoffman 2011, 64). 


\section{Statistics on vehicle smuggling detection by the Border Guard on the Podkarpackie section of the Polish-Ukrainian border in 2014-2020}

Comparison of the value of smuggling revealed in 2014-2020 by the Bieszczady Border Guard Unit (Podkarpacie section of the Polish-Ukrainian border) and the Bug River Border Guard Unit (Lublin section of the PolishUkrainian border) with the division into border crossings in Dorohusk and Hrebenne in Figures 1-2.

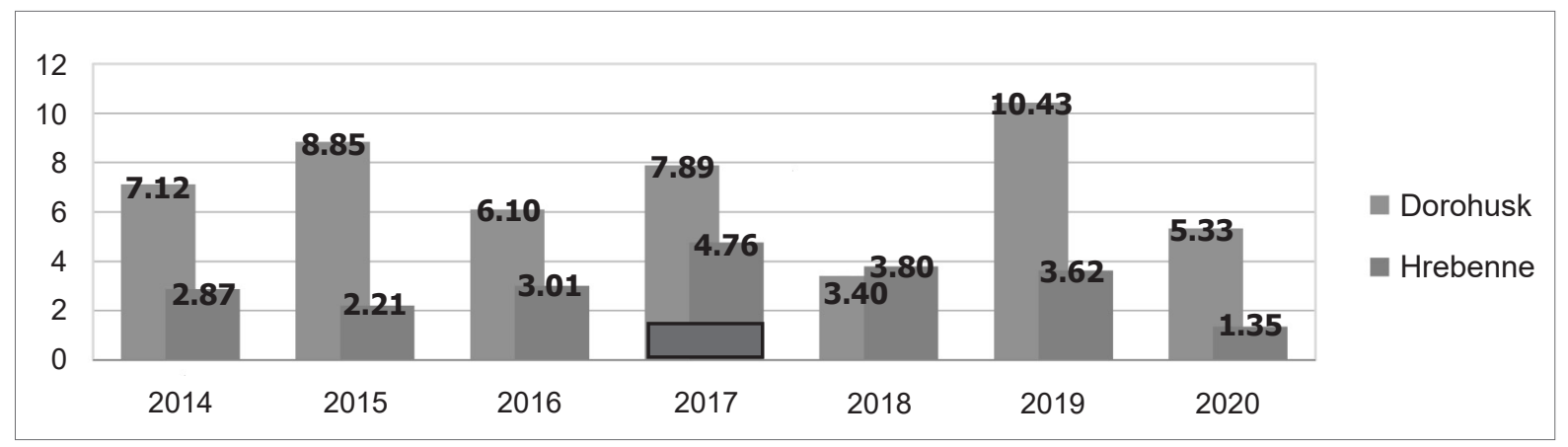

Figure 1. Value of the smuggling of goods disclosed by the Bug River Border Guard Unit in 2014-2020 (in millions of zloty).

Source: Own study based on materials from the Bieszczady Border Guard Department.

Figure 1 shows the value of goods derived from crime and prohibited goods that were disclosed by officers of the Bug River Border Guard Department in 2014-2020. The goods were revealed at the road border crossings in Dorohusk and Hrebenne. There are significant differences in the value of the goods disclosed at both border crossing points located in the Lubelskie Voivodeship. In 2019, Dorohusk recorded the highest value of seized goods (over PLN 10 million), of which drugs constituted the largest percentage (over PLN 6 million). 57 vehicles with a total value of almost PLN 3 million were stopped. The highest value of goods retained in Hrebenne (PLN 4.76 million) was recorded in 2017. At that time, 58 vehicles with a total value of almost PLN 1.2 million were stopped. In 2020, a significant decrease in the value of the disclosed goods was recorded (Dorohusk - PLN 5.33 million, Hrebenne - PLN 1.35 million), which is related to the COVID-19 epidemic and the closure of border crossings. At that time, 45 vehicles worth PLN 2.7 million were seized in Dorohusk, and 11 vehicles worth over PLN 1 million and vehicle components worth PLN 93 thousand in Hrebenne.

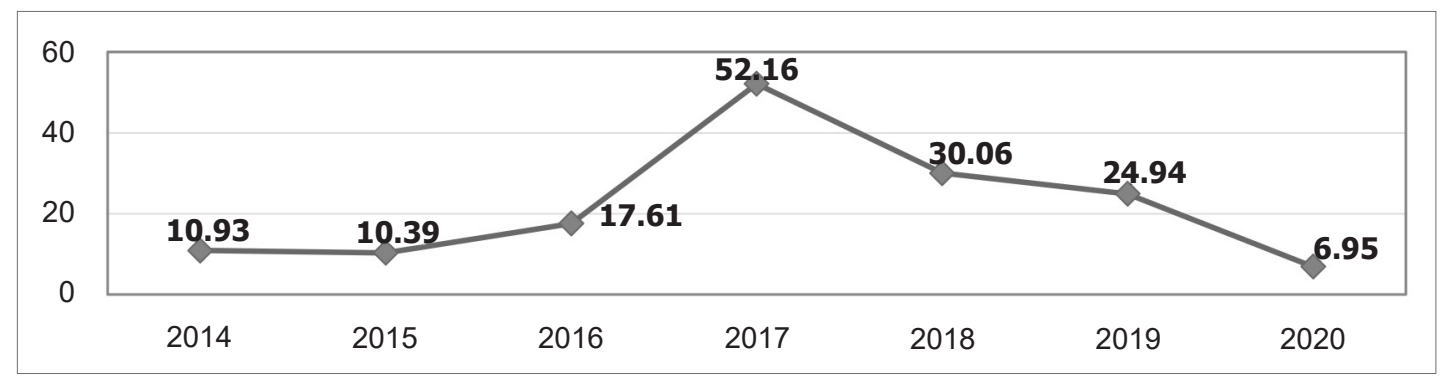

Figure 2. The value of the smuggling of goods disclosed by the Bieszczadzki Branch of the Border Guard in 2014-2020 (in millions of zlotys).

Source: Own study based on materials from the Bieszczady Border Guard Department.

In 2014 and 2015, the value of smuggling on the Podkarpackie section of the Polish-Ukrainian border was around PLN 10 million. In 2016, the value increased to PLN 17.6 million. The largest increase was recorded in 2017 - the value of disclosed smuggling reached PLN 52 million. In the following years, there was a significant decrease, to the level of PLN 6.95 million in 2020, which was also caused by the COVID-19 epidemic and the closure of state borders. 
Example 1. Estimated value: PLN 200,000 Car: Volvo XC60, manufactured in 2019. Place of detention: Przemyśl, Time of detention: October 2019 Circumstances: The car was parked in an unusual place in Przemyśl, which aroused suspicion of border guards. They carried out an initial check of the legality of its origin. After a few minutes, two young men - residents of Przemyśl - approached the uniformed men. They were deeply disturbed by the activities of the officers. They were going to drive the vehicle away. As a result of checks with international search bases, it was found that the vehicle had been stolen just a day earlier in Germany. Source: Own study based on materials from the Bieszczady Border Guard Department.

Example 2. Estimated value: PLN 500,000, Car: BMW 745, manufactured in 2019. Place of detention: Wołomin, Mazowieckie voivodship, Time of detention: September 2019 Circumstances: information about an exclusive BMW limousine originating from a crime was obtained by officers Border Guard from the Car Crime Prevention Team operating in the Bieszczady Border Guard Department. Source: Own study based on materials from the Bieszczady Border Guard Department.

Smuggling revealed in 2014-2020 in the Subcarpathian Border Guard Posts in Korczowa, Medyka and Krościenko, broken down into individual groups of goods.

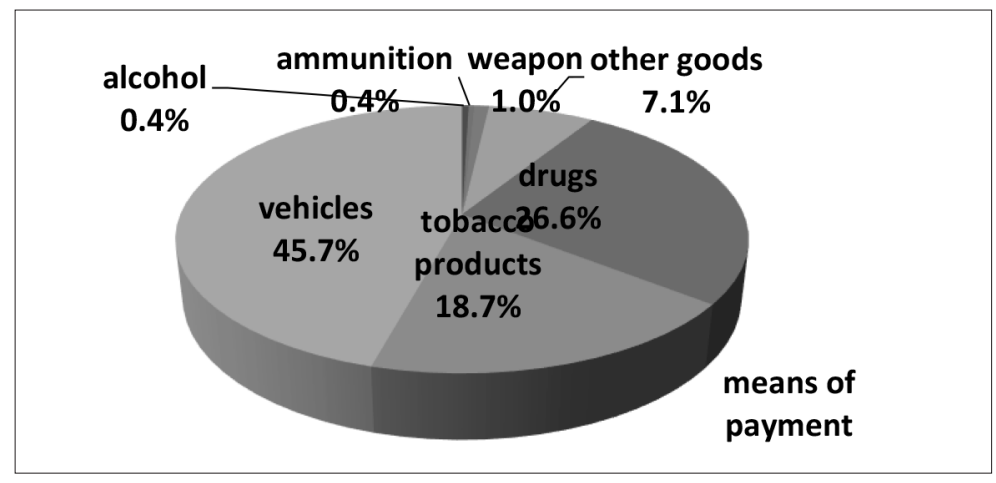

Figure 3. Smuggling disclosed at the Border Guard Post in Korczowa in 2014-2020, broken down into individual goods.

Source: Own study based on materials from the Bieszczady Border Guard Department.

Figure 3 shows the smuggling of goods disclosed at the Border Guard Post in Korczowa in 2014-2020, broken down by groups of goods. Detained vehicles accounted for the highest percentage of smuggling - as much as $45.7 \%$ of the total value.

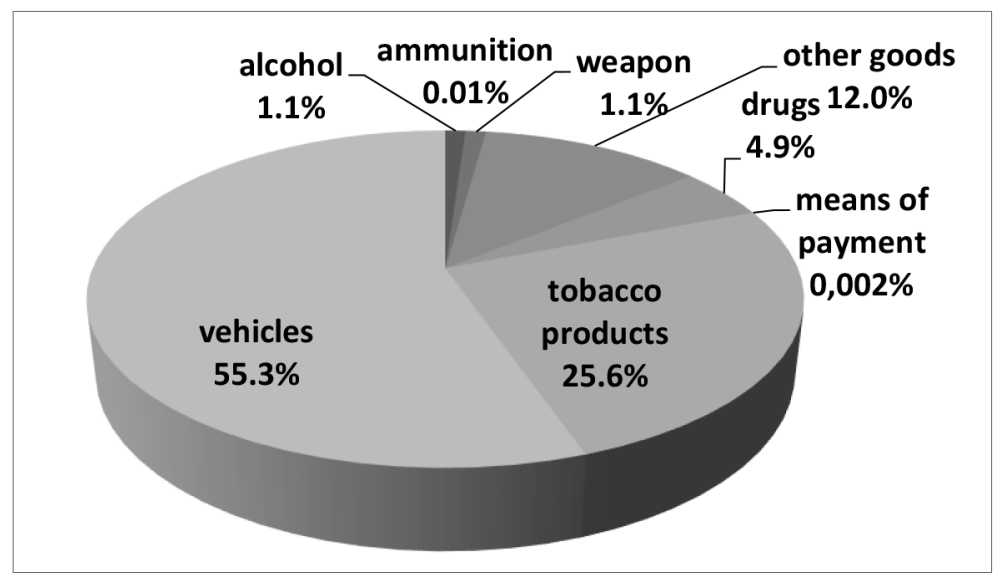

Figure 4. Smuggling disclosed at the Border Guard Post in Medyka in 2014-2020, broken down by individual goods.

Source: Own study based on materials from the Bieszczady Border Guard Department.

Figure 4 shows the smuggling disclosed at the Border Guard Post in Medyka in 2014-2020, broken down by groups of goods. Detained vehicles accounted for over 55\% of the value of smuggling. Among other goods disclosed by PSG officers in Medyka were car and motorcycle parts, license plates and engines. 


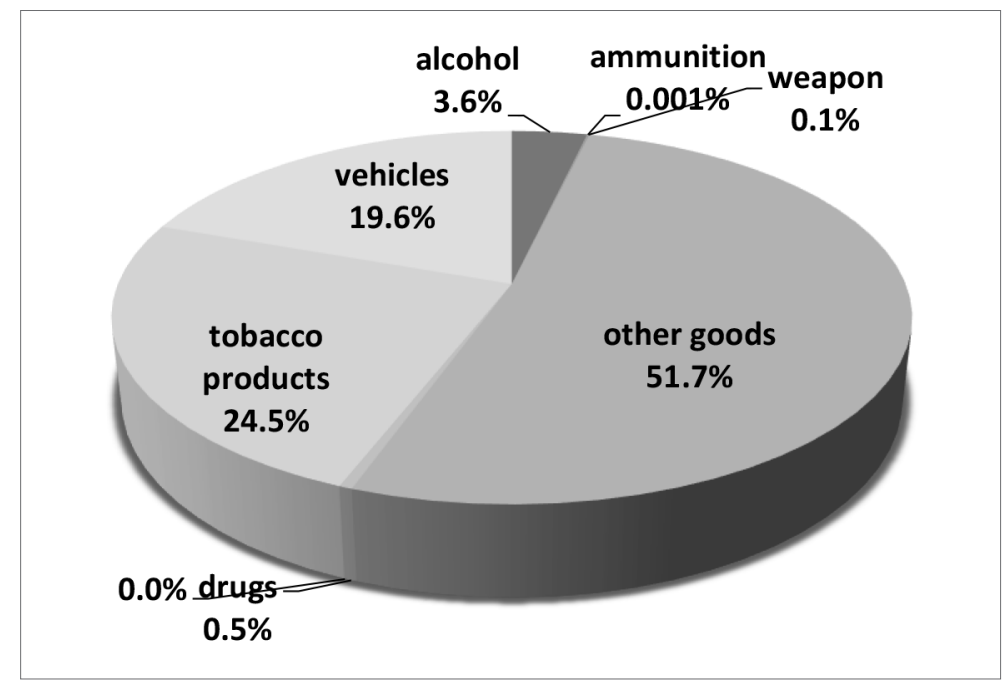

Figure 5. Smuggling disclosed at the Border Guard Post in Krościenko in 2014-2020, broken down into individual goods.

Source: Own study based on materials from the Bieszczady Border Guard Department.

Figure 5 presents smuggling disclosed at the Border Guard Post in Krościenko in 2014-2020, broken down by individual goods. $51.7 \%$ of the total value of smuggling was constituted by other goods, including mechanical devices, car and motorcycle parts, engines, license plates, diesel oil and gasoline. Tobacco products accounted for $24.5 \%$ of the value of disclosed smuggling. Vehicles came third in less than $20 \%$ of the total value of smuggling. When comparing the above data, it should be emphasized that the vehicles were the goods that constituted the highest value among the smuggling found in the Border Guard Posts in Korczowa, Medyka and Krościenko in the years 2014-2020. Tobacco products were in second place.

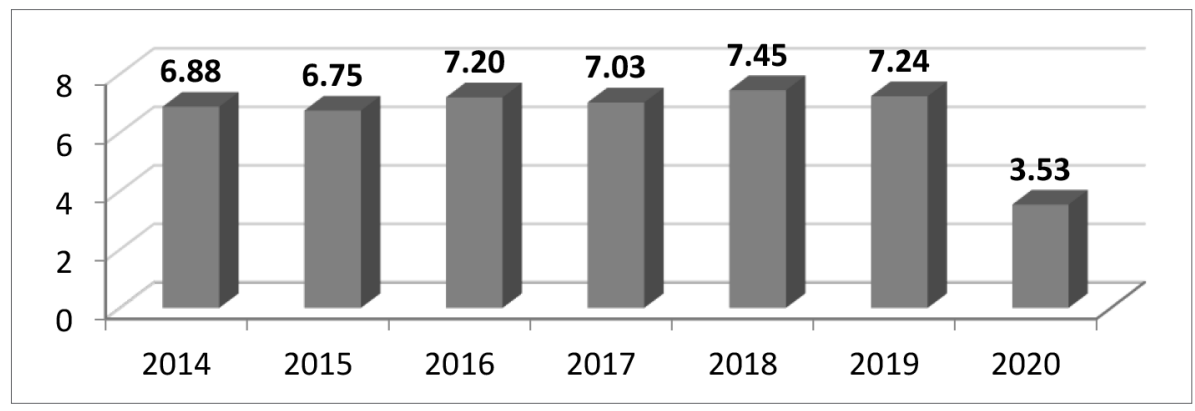

Figure 6. The value of vehicle smuggling in 2014-2020 on the Podkarpackie section of the Polish-Ukrainian border in 2014-2020 (in millions of zlotys).

Source: Own study based on materials from the Bieszczady Border Guard Department.

Vehicle smuggling on the Podkarpackie section of the Polish-Ukrainian border in 2014-2020 is shown in Figure 6. The value of vehicle smuggling disclosed in the Podkarpackie Voivodeship in 2014-2020 remained at a similar level for a very long time. In the years 2014-2019 it ranged from PLN 6.7 to 7.5 million with slight variations. By 2016, smuggling in the amount of about PLN 7 million was disclosed. In 2020, there was a decrease in the value of disclosed vehicles to PLN 3.53 million, which was caused by the pandemic and the closure of state borders, thus limiting smuggling. At that time, officers of the Bieszczady Border Guard Department stopped 64 stolen vehicles. Most of them were passenger cars, but there were also trucks, excavators, and even a tanker trailer. Almost 40 had lost vehicle status in international search bases. Some were stolen from the rental shop, while others were falsified identification numbers. The greatest smuggling of vehicles takes place in facilities with highly developed infrastructure, where smugglers try to use very high border traffic. 
The Border Guard statistics show a very significant, as much as $30 \%$ increase in the number of disclosed parts that have been dismantled from stolen cars. This is how criminals intend to transfer them beyond the external border of the European Union.

\section{Conclusions}

The statistics of disclosed vehicle smuggling show the high effectiveness of the Border Guard in detecting this illegal practice, which is also significantly influenced by cooperation with other national and international services, thanks to which information exchange and shaping the tactics of operations takes place.The Border Guard has the most modern vehicles and devices that help to reveal and detain smuggled goods and smugglers, but they are not able to completely discourage smugglers who monitor the activities of the services carefully analyzing the course of checks carried out by individual officers. This is very valuable information for the smugglers, as the hidden goods usually end up with an officer who has little experience or is not very inaccurate in carrying out control activities. It should be emphasized that the Border Guard does not have a sufficient number of officers who are specialists in the field of vehicle smuggling detection. In 2020, the value of the disclosed vehicles decreased to the level of PLN 3.53 million in the Podkarpackie section of the Polish-Ukrainian border. The coronavirus outbreak and related border crossing restrictions have caused traffic to drop by over $65 \%$. The number of stolen vehicles in 2020 was halved compared to 2019 , but even a slight increase in theft is noticeable in the luxury vehicle segment. It also covers illegal transactions related to the sale of spare parts. These markets show the specificity of Eastern European crime. In addition to the so-called car crimes include thefts of agricultural machinery (mainly tractors), construction equipment as well as yachts and engines used in motor boats. The challenge for the state authorities is the activity of exports to the so-called "Reporting", smuggling by finding twin cars and smuggling and registering cars through substitution. Such activities focus mainly on the border with Belarus and Ukraine. In 2020, there was an almost $30 \%$ increase in the number of disclosed parts from lost cars. In total, there were over 1.9 thousand of them. pieces, with a total value of over PLN 1 million. This means that the disassembly of stolen vehicles and the attempt to smuggle them in parts outside the European Union is a very important problem at present.

\section{References:}

Act of October 12, 1990 on the Border Guard (Ustawa z 12 października 1990 r. o Straży Granicznej (tekst jedn. Dz. U. z 2005 r. Nr 234 , poz. 1997 ze zm.).

Bąk T. (2011). Cross-border security of Poland (Bezpieczeństwo transgraniczne Polski). Zeszyty Naukowe WSOWL, 3 (161).

Chwała K. (2011), Fighting organized crime in the aspect of Polish-Ukrainian cooperation (Zwalczanie przestępczości zorganizowanej w aspekcie wspótpracy polsko-ukraińskiej) Ed. Grochowski, A. Letkiewicz, A.

Misiuk (red.) (2011). Safety science. The essence, subject of research and development directions (Nauka o bezpieczeństwie. Istota, przedmiot badań i kierunki rozwoju). Studia i materiały), 2, Szczytno.

Hoffman T. (2011). Border Guard and the protection of the Polish state border and the border of the European Union (Straż Graniczna a ochrona polskiej granicy państwowej i granicy Unii Europejskiej). Przegląd Naukowo-Metodyczny. Edukacja dla Bezpieczeństwa, 2.

Jurgilewicz M. et al. (2011). Legal aspects of road safety, (Prawne aspekty bezpieczeństwa ruchu drogowego), Warszawa.

Kamuda D., Trybus M. (2013). The Border Guard and its tasks in the field of the protection of the national security of the Republic of Poland - an outline of the issues (Straż Graniczna i jej zadania w zakresie ochrony bezpieczeństwa narodowego Rzeczypospolitej Polskiej - zarys problematyki), Humanities and Social Sciences, 20(3).

Laskowska K. (2011). Areas of activity of organized crime groups in Poland (Obszary działalności zorganizowanych grup przestęczych w Polsce), [In] E.W. Pływaczewski (red.), Organized crime (Przestępczość zorganizowana), Warszawa.

Łachacz O., Łachacz R. (2012). Car crime (Przestęczość samochodowa), [In] Illegal markets. Genesis, scale of the phenomenon and possible countermeasures (Nielegalne rynki. Geneza, skala zjawiska oraz możliwości przeciwdziałania), W. Pływaczewski, P. Chlebowicz (red.), Olsztyn.

Majer P., Seroka M. (2017). 225 years of the police in Poland The genesis and evolution of the police (225 lat policji w Polsce Geneza 
i ewolucja policji), Wydział Prawa i Administracji Uniwersytetu Warmińsko-Mazurskiego w Olsztynie, Olsztyn.

Maksimczuk A., Sidorowicz L. (2008). Border services for passenger and goods traffic in the European Union. Selected aspects (Graniczna obstuga ruchu osobowego i towarowego w Unii Europejskiej. Wybrane aspekty), AlmaMer, Warszawa.

Mroczek A. (2011). Fighting organized crime (Zwalczanie przestępczości zorganizowanej), [w:] Transsectoral areas of national security (Transsektorowe obszary bezpieczeństwa narodowego), K. Liedel (red.), Difin, Warszawa 2011.

Pływaczewski W. (2001). Contemporary trends in organized crime in Europe (analysis of selected criminal phenomena taking into account the tasks of the European Union Agency for Law Enforcement Cooperation EUROPOL) (Wspótczesne trendy przestepczości zorganizowanej w Europie (analiza wybranych zjawisk przestępczych z uwzględnieniem zadań Agencji Unii Europejskiej ds. Wspótpracy Organów Ścigania EUROPOL). Studia Prawnoustrojowe, 52.

Potakowski D. (2008). Vehicle thefts in Poland and other European countries (Kradzieże pojazdów w Polsce i innych krajach europejskich). Przegląd Policyjny, 3.

Przeor M. (2016). Selected aspects of threats to the security of the external borders of the European Union (Wybrane aspekty zagrożeń bezpieczeństwa zewnętrznych granic Unii Europejskiej). OBRONNOŚĆ. Zeszyty Naukowe Wydziału Zarzadzania i Dowodzenia Akademii Sztuki Wojennej, 3(19).

Act of October 12, 1990 on the Border Guard <Ustawa z 12 października 1990 r. o Straży Granicznej (tekst jedn. Dz. U. z 2005 r. $\mathrm{Nr} 234$, poz. 1997 ze zm.)>.

Wiśniewska K. (2015). Border Guard - organization and operation characteristics on the example of the Bug River Border Guard Unit (Straż Graniczna - organizacja i charakterystyka funkcjonowania na przykładzie Nadbużańskiego Oddziału Straży Granicznej). Administracja, 1(5).

Wiśniewski B., Piątek Z. (2006). The contemporary dimension of the functioning of the Border Guard (Wspótczesny wymiar funkcjonowania Straży Granicznej), Akademia Obrony Narodowej, Warszawa.

Marek DELONG is the Professor at Rzeszów University of Technology, PL. Research interests: international security, policy, international relations.

ORCID ID: 0000-0001-7766-5834.

Marcin JURGILEWICZ is the Professor at Rzeszów University of Technology, PL. Research interests: internal security, law, mediation.

ORCID ID: $0000-0003-2243-2165$.

Oktawia JURGILEWICZ, Rzeszów University of Technology, PL. Research interests: internal security, environmental protection, criminal law.

ORCID ID: 0000-0003-1293-6933. 